\title{
KEPATUHAN KONSUMSI TABLET FE TERHADAP KENAIKAN KADAR HEMOGLOBIN IBU HAMIL TRIMESTER III
}

\author{
Herlina Tri Damailia ${ }^{(1)}$, Rizqi Amalia Nurhapsari ${ }^{(2)}$ \\ Prodi Kebidanan Magelang, Poltekkes Kemenkes Semarang \\ Telp.08121511809/Email: herlinadamai@gmail.com
}

\begin{abstract}
ABSTRAK
Anemia defisiensi besi merupakan salah satu gangguan yang paling sering terjadi terutama selama masa kehamilan. Pemberian tablet $\mathrm{Fe}$ merupakan salah satu program pemerintah Indonesia untuk mencegah terjadinya anemia pada ibu hamil. Kepatuhan mengkonsumsi tablet $\mathrm{Fe}$ dikatakan baik apabila ibu hamil mengkonsumsi semua tablet $\mathrm{Fe}$ dari jumlah, cara minum, dan waktu yang tepat selama kehamilan. Kepatuhan ibu hamil dalam mengkonsumsi tablet $\mathrm{Fe}$ juga dipengaruhi beberapa faktor, yang menurut hasil penelitian Alifah (2016) kepatuhan ibu hamil mengonsumsi tablet $\mathrm{Fe}$ yaitu pengetahuan, motivasi, dukungan keluarga, kunjungan ANC, dan efek tablet Fe. Tujuan dari penelitian ini adalah untuk mengetahui pengaruh kepatuhan konsumsi tablet Fe terhadap kenaikan kadar hemoglobin ibu hamil trimester III. Penelitian ini dilakukan di wilayah kerja Puskesmas Pringsurat Kabupaten Temanggung. Jenis penelitian adalah Preeksperimental dengan design One Group pretest-posttest. Populasi penelitian sebanyak 40 ibu hamil. Teknik pengambilan sample dengan menggunakan total sampling yang diambil pada bulan Maret April 2018. Analisis data dengan menggunakan uji T-Test Dependent. Data dianalisis menggunakan uji statistik T-Test Dependent dihasilkan $p$-value 0.001 atau $\alpha<0,05$ maka Ha diterima, sehingga dapat disimpulkan bahwa kenaikan kadar $\mathrm{Hb}$ dipengaruhi oleh kepatuhan responden mengkonsumsi tablet Fe. Saran dalam penelitian ini diharapkan ibu hamil agar mengkonsumsi tablet Fe dengan cara yang benar yaitu minum 1 kali sehari selama periode masa kehamilan minimal 90 tablet, meminum dengan cara yang benar dengan menggunakan air putih atau air jeruk, dan waktu minum yang benar yaitu diminum pada malam hari untuk mencegah mual dan dianjurkan melakukan pemanfaatan antenatal care untuk mendapat pengawasan terhadap konsumsi tablet Fe.
\end{abstract}

Kata Kunci: Kepatuhan, Tablet Fe, Kadar Hemoglobin

\section{COMPLIANCE OF FE TABLET CONSUMPTION TO INCREASE HEMOGLOBIN CONTENT OF PREGNANT WOMAN TRIMESTER III}

Iron deficiency anemia is one of the most common disorders especially during pregnancy. Provision of Fe tablets is one of the Indonesian government programs to prevent the occurrence of anemia in pregnant women. Compliance of Fe tablets is said to be good when pregnant women consume all Fe tablets from the amount, the way they drink, and the right time during pregnancy. Compliance of pregnant women in consuming Fe tablet also influenced by several factors, which according to Alifah (2016) compliance study of pregnant women consuming Fe tablet that is knowledge, motivation, family support, visit ANC, and Fe tablet effect

The purpose of this study was to determine compliance of Fe tablet consumption to increase levels of hemoglobin of pregnant women third trimester. This research was conducted in the working area of public center of Pringsurat Temanggung District.

Kind of research is a preexperimental method and design using One Group Pretest-Posttest approach. Sampling technique using total sampling taken in March - April 2018. Data analysis using T-test Dependent By using T-Test result p-value 0.001 or $\alpha<0,05$ hypothesis is accepted, so it can be concluded that the increase of $\mathrm{Hb}$ level is influenced by the compliance of the respondent consuming Fe tablet.

Suggestions in this study is expected pregnant mother to consume Fe tablet with correct way that is drinking 1 times a day during period of pregnancy minimum 90 tablets, drinking the right way by using water or orange juice, and correct drinking time that is drunk at night day to prevent nausea and is recommended to use antenatal care to get supervision on consumption of Fe tablets

Keywords: Compliance, Fe Tablet, Hemoglobin Level

BHAMADA, JITK, Vol. 10, No. 1, April 2019 


\section{PENDAHULUAN}

Masalah gizi utama di Indonesia yang belum teratasi salah satunya adalah anemia. Wanita Indonesia mengalami masalah anemia sebagai akibat kekurangan zat besi dan asam folat dalam tubuh serta faktor lain seperti penyakit infeksi, cacingan dan penyakit kronis (Tarwoto dan Wasnidar, 2013). ${ }^{1}$ Anemia defisiensi besi merupakan salah satu gangguan yang paling sering terjadi terutama selama masa kehamilan (Kristiyanasari, 2010). ${ }^{2}$

Anemia dapat didefinisikan sebagai kondisi dengan kadar $\mathrm{Hb}$ berada di bawah normal. Ibu hamil dinyatakan anemia jika hemoglobin $(\mathrm{Hb})$ $<11 \mathrm{mg} / \mathrm{L}$ (Kemenkes RI, 2015). ${ }^{3}$ Hemoglobin merupakan sel penyusun darah merah (eritrosit) yang bertugas mengikat oksigen dari paru dan membawanya ke seluruh tubuh, serta dalam pembentukannya hemoglobin membutuhkan zat besi (Wijayakusuma, 2008). ${ }^{4}$ Kekurangan zat besi sejak sebelum kehamilan bila tidak diatasi dapat mengakibatkan ibu hamil menderita anemia. Menurut Manuaba (2015) $)^{5}$ dampak anemia pada ibu hamil antara lain terjadinya abortus, persalinan premature, hambatan tumbuh kembang janin dalam rahim, mudah terjadi infeksi, mola hidatidosa, hyperemesis gravidarum, perdarahan antepartum dan ketuban pecah dini.

Menurut Fatmah $(2011)^{6}$, cara mengatasi kekurangan zat besi dalam tubuh yaitu dengan mengkonsumsi 60-120 mg Fe per hari dan meningkatkan asupan makanan sumber Fe.
Pemberian tablet Fe merupakan salah satu program pemerintah Indonesia untuk mencegah terjadinya anemia pada ibu hamil. Jumlah suplemen zat besi yang diberikan selama kehamilan ialah sebanyak 90 tablet (Fe3) dengan dosis $60 \mathrm{mg}$ (Kemenkes RI, 2015) ${ }^{3}$.

Meskipun upaya untuk mengurangi kejadian anemia pada kehamilan sudah dilaksanakan melalui pemberian satu tablet besi setiap hari, pada kenyataannya prevelensi anamia yang terjadi masih cukup tinggi. Menurut WHO (2008) kejadian anemia di dunia diperkirakan terjadi pada $41,8 \%$ ibu hamil, dan setengahnya disebabkan karena kekurangan zat besi. Berdasarkan hasil Riset Kesehatan Dasar (Riskesdas) $^{7}$ tahun 2013, prevalensi anemia pada ibu hamil di Indonesia sebesar 37,1\%. Sementara itu data yang ada pada Dinas Kesehatan Kabupaten Temanggung pada bulan Januari - September 2017 pemberian Fe 90 tablet sebesar 7.839 ibu hamil dan angka kejadian anemia ibu hamil sebesar 2.289 $(26,40 \%)$. Sedangkan data yang didapatkan dari Puskesmas Pringsurat bulan Januari September 2017 pemberian $\mathrm{Fe} 90$ tablet sebanyak $250 \mathrm{ibu}$ hamil dengan angka kejadian anemia $76,6 \%$.

Setelah mengkonsumsi tablet $\mathrm{Fe}$ terdapat beberapa efek samping seperti mual, muntah, kram lambung, nyeri ulu hati, konstipasi, dan kadang-kadang diare (Jordan, 2004) ${ }^{8}$. Banyaknya efek samping tersebut terkadang menimbulkan ibu hamil tidak patuh dalam 
mengkonsumsi tablet Fe sehingga menyebabkan masih tingginya anemia pada ibu hamil.

Penyerapan zat besi dipengaruhi oleh banyak faktor, protein hewani dan vitamin $\mathrm{C}$ meningkatkan penyerapan. Kopi, teh, garam kalsium, magnesium, dan fitat dapat mengikat zat besi (Fe) sehingga mengurangi jumlah resapan (Arisman, 2010) ${ }^{9}$. Tingkat keasaman dalam lambung ikut mempengaruhi kelarutan dan penyerapan zat besi di dalam tubuh. Suplemen zat besi lebih baik dikonsumsi pada saat perut kosong atau sebelum makan, karena zat besi akan lebih efektif diserap apabila lambung dalam keadaan asam (ph rendah).

Menurut Saragi $(2011)^{10}$, kepatuhan (Compliance) dalam pengobatan dapat diartikan sebagai perilaku pasien yang menaati semua nasihat dan petunjuk yang dianjurkan oleh kalangan tenaga medis, seperti dokter dan Apoteker mengenai segala sesuatu yang harus dilakukan untuk mencapai tujuan pengobatan, salah satu diantaranya adalah kepatuhan dalam minum obat. Kepatuhan dalam mengkonsumsi tablet $\mathrm{Fe}$ adalah ketaatan ibu hamil melaksanakan anjuran petugas kesehatan untuk mengkonsumsi tablet zat besi yang diukur dari ketepatan jumlah yang dikonsumsi, cara konsumsi, dan frekuensi konsumsi zat besi per hari.

Kepatuhan ibu hamil dalam mengkonsumsi tablet Fe juga dipengaruhi beberapa faktor, yang menurut hasil penelitian Alifah (2016) ${ }^{11}$ kepatuhan ibu hamil mengonsumsi tablet Fe yaitu pengetahuan, motivasi, dukungan keluarga, kunjungan ANC, dan efek tablet Fe. Menurut Purbadewi (2013) ${ }^{12}$, ibu hamil yang berpengetahuan kurang tentang tablet $\mathrm{Fe}$ akan berperilaku negatif, sedangkan yang berpengetahuan baik akan berperilaku positif, dalam hal ini adalah perilaku untuk mencegah atau mengobati anemia. Menurut Budiarni (2012) ${ }^{13}$, motivasi yang baik dalam mengkonsumsi tablet $\mathrm{Fe}$ timbul karena keinginan untuk mencegah anemia dan menjaga kesehatan ibu hamil dan janinnya. Semakin baik motivasi maka semakin patuh mengkonsumsi tablet Fe.

Jumlah ibu hamil di Kabupaten Temanggung sampai bulan September 2017 sebanyak 8668 ibu hamil dengan 2289 (26,40\%) mengalami anemia, dan di Wilayah Kerja Puskesmas Pringsurat sebanyak 291 ibu hamil dengan $223(76,6 \%)$ ibu hamil diantaranya mengalami anemia. Dari hasil wawancara pada tanggal 19 - 20 Oktober 2017 terhadap $10 \mathrm{ibu}$ hamil yang melakukan pemeriksaan di Puskesmas Pringsurat, didapatkan hasil sebanyak 4 ibu hamil mengkonsumsi Fe dengan menggunakan air putih dan 3 Ibu hamil mengkonsumsi Fe menggunakan air teh, dan terdapat 3 ibu hamil yang menyatakan tidak setiap hari minum tablet Fe karena lupa dan tidak enak baunya dan berdasarkan hasil pemeriksaan hemoglobin, 7 ibu hamil mengalami anemia.

\section{METODE PENELITIAN}


Jenis penelitian ini merupakan penelitian Preeksperimental dengan Design One Group pretest-posttes. Variabel independen dalam penelitian ini adalah jumlah, waktu, dan cara minum tablet Fe. Variabel dependen dalam penelitian ini adalah peningkatan kadar $\mathrm{Hb}$. Penelitian ini dilakukan di wilayah kerja Puskesmas Pringsurat Kabupaten Temanggung. Populasi penelitian sebanyak $40 \mathrm{ibu}$ hamil. Teknik pengambilan sampel dengan menggunakan total sampling yang diambil pada bulan Maret - April 2018. Peneliti melakukan test $\mathrm{Hb}$ sebelum perlakuan kepatuhan, kemudian selama 14 hari diberikan tablet Fe $60 \mathrm{mg}$ dan diminum bersama vitamin C. Dari 40 ibu hamil yang diberikan perlakuan kepatuhan maka hanya 29 ibu hamil yang patuh, ibu hamil yang patuh dalam metode pengambilan sampel penelitian ini adalah ibu hamil yang patuh dalam jumlah tablet $\mathrm{Fe}$ yang diminum, waktu minum, dan cara minum tablet $\mathrm{Fe}$ yaitu sejumlah $29 \mathrm{ibu}$ hamil, jadi total sampel dalam penelitian ini adalah $29 \mathrm{ibu}$ hamil. Analisis data dengan menggunakan uji T-Test Dependent.

Data primer untuk penelitian ini adalah data kepatuhan konsumsi tablet Fe yang dinilai dari jumlah, cara minum, dan waktunya diperoleh melalui lembar observasi, serta data kadar $\mathrm{Hb}$ ibu hamil trimester III menggunakan Haemometer digital. Data sekunder untuk penelitian ini dilakukan dengan mengambil data kohort ibu hamil atau buku KIA yang tinggal diwilayah Puskesmas Pringsurat Kabupaten Temanggung.

Analisis data penelitian dilakukan dengan cara sebagai berikut : analisis univariat untuk mengetahui prosentase dari setiap variabel. Analisis bivariat dilakukan dengan uji T-Test Dependent, dengan tingkat kesalahan $(\alpha)$ $5 \%=0,05$ dengan derajat kepercayaan $95 \%$. Ketentuan pengujian, apabila nilai $\mathrm{p}$ value $<0,05$ maka Ha diterima dan Ho ditolak. Analisis statistik menggunakan program SPSS. (Sopiyudin, 2012) ${ }^{14}$.

\section{HASIL PENELITIAN}

\section{Analisis Univariat}

a. Kepatuhan Konsumsi Tablet Fe pada Ibu Hamil Trimester III

Tabel.1 Kepatuhan Konsumsi Tablet Fe pada Ibu Hamil Trimester III

\begin{tabular}{lcc}
\hline Kategori & Frekuensi & Persentase $(\%)$ \\
\hline Patuh & 29 & 72,5 \\
Tidak Patuh & 11 & 27,5 \\
\hline
\end{tabular}

Berdasarkan tabel 1 menunjukkan bahwa ibu hamil Trimester III patuh mengkonsumsi tablet $\mathrm{Fe}$ yaitu 29 responden $(72,5 \%)$ dan yang tidak patuh 11 responden $(27,5 \%)$. Dalam penelitian ini maka yang dianalisis secara bivariat adalah responden yang patuh saja.

b. Kadar Hb Sebelum Diberikan Perlakuan Kepatuhan Konsumsi Tablet Fe

Tabel.2 Distribusi Frekuensi Kadar $\mathrm{Hb}$ Sebelum Diberikan Perlakuan Kepatuhan

\begin{tabular}{ccc}
\hline $\begin{array}{c}\text { Kadar Hb } \\
(\mathrm{g} / \mathrm{dl})\end{array}$ & Frekuensi & Persentase $(\%)$ \\
\hline 7,2 & 1 & 3,4 \\
\hline
\end{tabular}




\begin{tabular}{ccc}
\hline 9 & 2 & 6,9 \\
9,9 & 1 & 3,4 \\
10 & 4 & 13,8 \\
11 & 6 & 20,7 \\
11,2 & 1 & 3,4 \\
11,3 & 1 & 3,4 \\
11,7 & 1 & 3,4 \\
11,8 & 1 & 3,4 \\
11,9 & 1 & 3,4 \\
12 & 4 & 13,8 \\
12,2 & 1 & 3,4 \\
12,4 & 1 & 3,4 \\
12,6 & 1 & 3,4 \\
13 & 1 & 3,4 \\
15,5 & 1 & 3,4 \\
15,8 & 1 & 3,4 \\
\hline Jumlah & 29 & 100 \\
\hline
\end{tabular}

\begin{tabular}{ccc}
\hline 12,4 & 2 & 6,9 \\
12,8 & 1 & 3,4 \\
13 & 1 & 3,4 \\
13,1 & 1 & 3,4 \\
15,5 & 1 & 3,4 \\
16 & 1 & 3,4 \\
\hline Jumlah & 29 & 100 \\
\hline
\end{tabular}

Berdasarkan Tabel 3. dapat dilihat bahwa kadar $\mathrm{Hb}$ setelah diberikan perlakuan kepatuhan konsumsi tablet $\mathrm{Fe}$ sebagian besar ibu hamil dengan kadar $\mathrm{Hb}$ 11,2 gr/dl sebanyak 5 responden (10\%), dengan kadar $\mathrm{Hb}$ tertinggi sebesar $16 \mathrm{gr} / \mathrm{dl}$, dan yang terendah $8 \mathrm{gr} / \mathrm{dl}$.

Tabel 2 menunjukkan bahwa kadar Hb sebelum diberikan perlakuan kepatuhan konsumsi tablet $\mathrm{Fe}$ sebagian besar ibu hamil dengan kadar $\mathrm{Hb}$ $11 \mathrm{gr} / \mathrm{dl}$ sebanyak 6 responden $(20,7 \%)$, dengan kadar $\mathrm{Hb}$ tertinggi 15,8 gr/dl dan yang terendah $7,2 \mathrm{gr} / \mathrm{dl}$.

c. Kadar Hb Setelah Diberikan Perlakuan Kepatuhan Konsumsi Tablet Fe

\section{d. Perubahan Kadar Hb Ibu Hamil Trimester III}

Tabel.4 Distribusi Frekuensi Perubahan Kadar Hb Ibu Hamil

\begin{tabular}{ccccc}
\hline $\begin{array}{c}\text { No } \\
\text { Resp }\end{array}$ & $\begin{array}{c}\text { Kadar Hb } \\
\text { Pre Test } \\
(\mathrm{gr} / \mathrm{dl})\end{array}$ & $\begin{array}{c}\text { Kadar Hb Kenaikan } \\
\text { Post Test } \\
(\mathrm{gr} / \mathrm{dl})\end{array}$ & $\begin{array}{c}(\mathrm{gr} / \\
\mathrm{dl})\end{array}$ & Keterangan \\
\hline 1 & 9 & 10.8 & 1.8 & Naik \\
2 & 9 & 9.5 & 0.5 & Naik \\
3 & 12 & 12 & 0 & Tetap
\end{tabular}

Tabel.3 Distribusi Frekuensi Kadar $\mathrm{Hb}$ Setelah Diberikan Perlakuan Kepatuhan

\begin{tabular}{ccc}
\hline $\begin{array}{c}\text { Kadar Hb } \\
(\mathrm{g} / \mathrm{dl})\end{array}$ & Frekuensi & $\begin{array}{c}\text { Persentase } \\
(\%)\end{array}$ \\
\hline 8 & 1 & 3,4 \\
9,5 & 1 & 3,4 \\
10 & 3 & 10,3 \\
10,3 & 1 & 3,4 \\
10,4 & 1 & 3,4 \\
10,8 & 1 & 3,4 \\
11 & 2 & 6,9 \\
11,2 & 5 & 17,2 \\
11,3 & 1 & 3,4 \\
11,8 & 1 & 3,4 \\
11,9 & 1 & 3,4 \\
12 & 1 & 3,4 \\
12,1 & 1 & 3,4 \\
12,2 & 1 & 3,4 \\
12,3 & 1 & 3,4 \\
\hline
\end{tabular}




\begin{tabular}{ccccc}
29 & 11.7 & 11.9 & 0.2 & Naik \\
31 & 12.2 & 12.4 & 0.2 & Naik \\
32 & 12.4 & 12.4 & 0 & Tetap \\
35 & 11 & 11.2 & 0.2 & Naik \\
38 & 11 & 11.4 & 0 & Naik \\
39 & 10 & 10 & 0 & Tetap \\
40 & 10 & 10.3 & 0.3 & Naik \\
\hline
\end{tabular}

e. Kenaikan Kadar Hb Ibu Hamil Trimester III

Tabel 5. Distribusi Frekuensi Kadar Hb Ibu Hamil

\begin{tabular}{ccc}
\hline Kategori & Frekuensi & $\begin{array}{c}\text { Persentase } \\
(\%)\end{array}$ \\
\hline Turun & 0 & 0 \\
Tetap & 9 & 31 \\
Naik & 20 & 69,0 \\
\hline Jumlah & 29 & 100 \\
\hline
\end{tabular}

Tabel 5 menunjukkan bahwa sebagian besar ibu hamil trimester III mengalami kenaikan kadar hemoglobin yaitu sebanyak 20 responden (69\%), yang tetap 9 responden $(31 \%)$ dan tidak ada responden yang turun kadar $\mathrm{Hb}$ nya.

\section{Analisis Bivariat}

Kepatuhan Konsumsi Tablet Fe Terhadap Kenaikan Kadar Hb Ibu Hamil Trimester III

Tabel.6 Uji T-Test Dependent

\begin{tabular}{lll}
\hline Kategori & Mean & Sig (2-tailed) \\
\hline $\mathrm{Hb}$ & & \\
Pretest & & \\
$\mathrm{Hb}$ & 2.517 & 0.001 \\
Posttest & & \\
\hline
\end{tabular}

Berdasarkan analisis statistik tabel 6 diperoleh hasil uji T-Test Berpasangan adalah dengan mean 2,517 dan p-value (sig 2-tailed) 0,001 atau $\alpha<0,05$ maka Ho ditolak dan Ha diterima. Sehingga dapat disimpulkan bahwa kenaikan kadar $\mathrm{Hb}$ dipengaruhi oleh kepatuhan responden mengkonsumsi tablet $\mathrm{Fe}$ dalam hal jumlah, waktu minum, dan cara minum.

\section{PEMBAHASAN}

Berdasarkan hasil penelitian ini menunjukkan bahwa kepatuhan konsumsi Fe pada ibu hamil trimester III yaitu sebanyak 29 responden $(100 \%)$. Sedangkan hasil uji analisis data dengan uji T-Test Dependent dengan hasil $p$ value pada kelompok intervensi adalah 0,001 < $\alpha(0,05)$ yang artinya kepatuhan konsumsi tablet $\mathrm{Fe}$ berpengaruh terhadap kenaikan kadar hemoglobin pada ibu hamil trimester III, sehingga hipotesis kerja (Ha) diterima. Patuh dalam mengkonsumsi tablet Fe menurut Jordan $(2004)^{8}$ adalah memisahkan minum teh, kopi, dan minuman karbonasi dan makan dengan masa selang satu jam, minum bersama vit C 200 mg atau bersama jus jeruk akan meningkatkan absorbsi zat besi dalam tubuh, sedangkan menurut Tarwoto \& Wasnidar (2013) ${ }^{1}$ ibu hamil selama masa kehamilannya harus minum tablet Fe setiap hari dengan kebutuhan zat besi pada trimester pertama relatif lebih sedikit yaitu sekitar 0,8 mg per hari, tetapi pada trimester kedua dan trimester ketiga meningkat menjadi 6,3 mg per hari. Ibu hamil dikatakan patuh minum tablet Fe menurut Hani, Ummi, dkk $(2010)^{15}$ yaitu minum pada malam hari untuk menghindari perasaan mual. Sehingga Kepatuhan mengkonsumsi tablet Fe dikatakan patuh apabila ibu hamil mengkonsumsi semua 
tablet Fe dari jumlah, cara minum, dan waktu yang tepat selama kehamilan.

Hasil penelitian ini sama dengan hasil penelitian Natalia $(2017)^{16}$ pada ibu hamil trimester III di Puskesmas Sindangwangi Majalengka yang juga menunjukkan sebagian besar ibu hamil patuh mengkonsumsi tablet Fe. Hal ini karena mengkonsumsi tablet Fe bagi ibu hamil sangat penting untuk mengatasi kebutuhan zat besi yang meningkat selama kehamilan.

Tablet Fe diberikan kepada ibu hamil selama kehamilannya minimal 90 tablet sejak pemeriksaan ibu hamil pertama, dan bermanfaat bila diminum setiap hari secara teratur selama kehamilan. Tablet Fe diminum dapat dengan air putih atau air jeruk dan baik jika diminum sebelum tidur. Tablet $\mathrm{Fe}$ jangan diminum dengan air teh, susu atau kopi karena dapat menurunkan penyerapan zat besi dalam tubuh sehingga manfaatnya menjadi berkurang (Fitrianingsih, 2010) ${ }^{17}$.

Ibu hamil yang patuh mengkonsumsi tablet Fe dapat disebabkan karena beberapa faktor, yang menurut hasil penelitian yang dilakukan oleh Kadir (2014) ${ }^{18}$, Faktor penyebab kepatuhan $\mathrm{ibu}$ hamil dalam mengkonsumsi tablet $\mathrm{Fe}$ diantara adalah faktor enabling (pemungkin) meliputi katersediaan sarana dan pra sarana atau fasilitas dan faktor reinforcing (penguat) meliputi dukungan keluarga, dukungan petugas kesehatan dan ketersediaan tablet Fe.
Kepatuhan ibu hamil dalam mengkonsumsi tablet Fe juga dipengaruhi beberapa faktor, yang menurut hasil penelitian Alifah (2016) ${ }^{11}$ kepatuhan ibu hamil mengonsumsi tablet Fe yaitu pengetahuan, motivasi, dukungan keluarga, kunjungan ANC, dan efek tablet Fe. Menurut Purbadewi (2013) ${ }^{12}$, ibu hamil yang berpengetahuan kurang tentang tablet $\mathrm{Fe}$ akan berperilaku negatif, sedangkan yang berpengetahuan baik akan berperilaku positif, dalam hal ini adalah perilaku untuk mencegah atau mengobati anemia. Menurut Budiarni $(2012)^{13}$, motivasi yang baik dalam mengkonsumsi tablet $\mathrm{Fe}$ timbul karena keinginan untuk mencegah anemia dan menjaga kesehatan ibu hamil dan janinnya. Semakin baik motivasi maka semakin patuh mengkonsumsi tablet Fe.

Berdasarkan hasil penelitian ini menunjukkan bahwa kadar $\mathrm{Hb}$ yang naik sebanyak 20 responden $(69,0 \%)$, dikatakan naik jika pada saat pemeriksaan akhir ada peningkatan kadar $\mathrm{Hb}$, sedangkan kadar $\mathrm{Hb}$ yang tetap ada 9 responden $(31,0 \%)$, dikatakan tetap jika kadar $\mathrm{Hb}$ pada awal pemeriksaan dan akhir pemeriksaan tidak mengalami perubahan kadar $\mathrm{Hb}$, dan tidak ada kadar $\mathrm{Hb}$ responden yang turun $(0 \%)$, dikatakan turun jika pada akhir pemeriksaan kadar hemoglobinnya lebih rendah dari hasil pemeriksaan awal sebelum diberikan perlakuan kepatuhan minum tablet Fe.

Kenaikan kadar hemoglobin ibu setelah mengkonsumsi tablet $\mathrm{Fe}$ dan vitamin $\mathrm{C}$ dapat 
disebabkan karena ibu patuh dalam mengkonsumsi tablet Fe, baik patuh dalam cara mengkonsumsi dan waktu mengkonsumsi serta jumlahnya. Mengkonsumsi tablet $\mathrm{Fe}$ dengan Vitamin $\mathrm{C}$ dapat meningkatkan penyerapan zat besi dalam tubuh karena vitamin $\mathrm{C}$ gugus $\mathrm{SH}$ (sulfidril) dan asam amino sulfur dapat meningkatkan absorbsi karena dapat mereduksi besi dalam bentuk ferri menjadi ferro. Vitamin $\mathrm{C}$ dapat meningkatkan absorbsi besi dari makanan melalui pembentukan kompleks ferro askorbat. Kombinasi $200 \mathrm{mg}$ asam askorbat dengan garam besi dapat meningkatkan penyerapan besi sebesar $25-50$ persen.

Penyerapan zat besi dipengaruhi oleh banyak faktor, protein hewani dan vitamin $\mathrm{C}$ meningkatkan penyerapan. Kopi, teh, garam kalsium, magnesium, dan fitat dapat mengikat zat besi (Fe) sehingga mengurangi jumlah resapan (Arisman, 2010) ${ }^{9}$. Tingkat keasaman dalam lambung ikut mempengaruhi kelarutan dan penyerapan zat besi di dalam tubuh. Suplemen zat besi lebih baik dikonsumsi pada saat perut kosong atau sebelum makan, karena zat besi akan lebih efektif diserap apabila lambung dalam keadaan asam (ph rendah).

Hasil penelitian juga menunjukkan sebanyak 9 responden $(31 \%)$ yang patuh mengkonsumsi tablet Fe tetapi kadar hemoglobinnya tetap. Hal ini dapat disebabkan karena ibu hamil mengalami pengenceran darah dianggap sebagai penyesuaian diri secara fisiologis dalam kehamilan dan bermanfaat bagi wanita.
Pertama-tama pengenceran itu meringankan beban jantung yang harus bekerja lebih berat dalam masa hamil, karena sebagai akibat hidremia cardiac output meningkat (Saifuddin, 2010) ${ }^{19}$.

Hipervolemia yang diinduksi oleh kehamilan mempunyai beberapa fungsi penting antara lain mengisi ruang vaskular di uterus, jaringan pembuluh di payudara, otot, ginjal dan kulit. Hipervolemia juga mengurangi efek pengeluaran hemogloblin pada persalinan. Penurunan kekentalan darah memperkecil resistensi terhadap aliran sehingga kerja jantung untuk mendorong darah menjadi lebih ringan. Faktor lain dari penyebab defisiensi $\mathrm{Fe}$ adalah meningkatnya kebutuhan $\mathrm{Fe}$ ibu hamil. Kebutuhan ibu hamil akan zat besi sebesar 900 mgr Fe, pada trimester dua (puncaknya usia kehamilan 32 sampai 34 minggu) akan terjadi hemodilusi (pengenceran darah) pada ibu hamil sehingga hemoglobin akan mengalami penurunan, mengakibatkan anemia kehamilan fisiologis.

Ibu hamil yang kadar hemoglobinnya tidak naik (tetap) meskipun patuh dalam mengkonsumsi tablet Fe juga dapat disebabkan karena asupan gizi ibu yang kurang dari kebutuhan, karena menurut Tarwoto \& Wasnidar $(2013)^{1}$ pada wanita hamil dengan janin tunggal kebutuhan zat besi sekitar 1000 mg selama hamil atau naik sekitar 200-300\%. Perkiraan besarnya zat besi yang perlu ditimbun selama hamil 1040 mg. Dari jumlah itu, 200 mg 
zat besi tertahan oleh tubuh ketika melahirkan dan $840 \mathrm{mg}$ sisanya hilang. Sebanyak $300 \mathrm{mg}$ besi ditransfer ke janin dengan rincian 50-75 mg untuk pembentukan plasenta, $450 \mathrm{mg}$ untuk menambah jumlah sel darah merah dan $200 \mathrm{mg}$ hilang ketika melahirkan.

Sumber zat besi yang baik adalah makanan hewani, seperti daging, ayam, dan ikan. Sumber baik lainnya adalah telur, serealia tumbuk, kacang-kacangan, sayuran hijau dan beberapa jenis buah. (Almatsier, 2010) ${ }^{20}$, sedangkan menurut Waryono (2010) ${ }^{21}$ makanan sumber Fe yang baik antara lain daging, ayam, ikan, telur, serealia tumbuk, kacang-kacangan, sayuran hijau, dan pisang ambon. Fe yang berasal dari makanan hewani lebih mudah diserap oleh tubuh daripada $\mathrm{Fe}$ yang berasal dari makanan nabati.

Penambahan asupan besi, baik lewat makanan dan/ atau pemberian suplemen terbukti mampu mencegah penurunan $\mathrm{Hb}$ akibat hemodilusi. Tanpa suplementasi, cadangan besi dalam tubuh ibu akan habis pada akhir kehamilan. Oleh karena itu suplemen sebesar 30-60 mg, dimulai pada minggu ke-12 kehamilan yang diteruskan sampai 3 bulan pasca partum, perlu diberikan setiap hari. (Arisman, 2010) ${ }^{9}$.

\section{KESIMPULAN DAN SARAN}

Kesimpulan

1. Kepatuhan konsumsi Fe pada ibu hamil trimester III yaitu sebanyak 29 responden (100\%).
2. Ibu hamil trimester III mengalami kenaikan kadar hemoglobin yaitu sebanyak 20 responden $(69 \%)$.

3. Kepatuhan konsumsi tablet $\mathrm{Fe}$ berpengaruh terhadap kenaikan kadar hemoglobin pada ibu hamil trimester III dengan p-value 0,001 $<\alpha(0,05)$.

Saran

\section{Untuk Ibu Hamil}

Diharapkan ibu hamil agar mengkonsumsi tablet $\mathrm{Fe}$ dengan cara yang benar yaitu minum 1 kali sehari selama periode masa kehamilan minimal 90 tablet, meminum dengan cara yang benar yaitu tidak menggunakan air teh, susu, atau kopi, sebaiknya menggunakan air putih atau air jeruk, dan waktu minum yang benar yaitu diminum pada malam hari untuk mencegah mual dan dianjurkan melakukan pemanfaatan antenatal care untuk mendapat pengawasan terhadap konsumsi tablet Fe.

\section{Untuk Bidan}

Bidan dapat meningkatkan kesadaran ibu hamil seperti memberi informasi jumlah tablet Fe yang harus diminum selama periode masa kehamilan, cara minum yang benar, dan waktu minum yang tepat, serta memantau kepatuhan ibu hamil dalam mengkonsumsi tablet $\mathrm{Fe}$ agar ibu hamil benar-benar menerapkannya.

3. Untuk Penelitian Selanjutnya

Bagi peneliti lain juga diharapkan dapat meneliti faktor-faktor lain yang berhubungan 
dengan peningkatan kadar hemoglobin pada ibu hamil seperti memantau konsumsi makanan ibu hamil.

\section{Ucapan Terimakasih}

Terimakasih kepada pimpinan yang telah memberikan kesempatan dan dukungan kepada peneliti untuk melakukan penelitian bersama mahasiswa. Terima kasih kepada teman sejawat dan mahasiswa yang telah berkontribusi dalam pelaksanaan kegiatan penelitian. Penelitian ini menggunakan sumber pembiaayaan mandiri oleh peneliti.

\section{DAFTAR PUSTAKA}

1. Tarwoto \& Wasnidar. 2013. Buku Saku Anemia Pada Ibu Hamil, Konsep dan penatalaksanaan. Jakarta: Trans Info Media.

2. Kristiyanasari, W. 20150. Gizi Ibu Hamil. Yogyakarta: Nuha Medika

3. Kementerian Kesehatan RI. 2015. Pusat Data dan Informasi Kementerian Kesehatan RI Situasi dan Analisis Gizi. Jakarta

4. Wijayakusuma, H. 2008. Ramuan Lengkap Herbal Taklukkan Penyakit. Jakarta:Pustaka Bunda.

5. Manuaba. 2015. Pengantar Kuliah Obstetri. Jakarta : ECG.

6. Fatmah. 2011. Gizi dan Kesehatan Masyarakat/ Departemen Gizi dan Kesehatan Masyarakat. Jakarta: Rajawali Pers.

7. Riset Kesehatan Dasar. 2013. Jakarta: Kemenkes.

8. Jordan, S. 2004. Farmakologi Kebidanan. Penerjemah: Andry Hartono. Jakarta: EGC.

9. Arisman. 2010. Buku Ajar Ilmu Gizi, Gizi dalam Daur Kehidupan. Jakarta: EGC.

10. Saragi, S. 2011. Panduan Penggunaan Obat. Jakarta: Rosemata Publisher.

11. Alifah, Nur Rizqi. 2013. Faktor - Faktor Yang Mempengaruhi Kepatuhan Ibu Hamil Mengkonsumsi Tablet Fe di Puskesmas Gamping II. http://repository.umy.ac.id/bitstream/handle
/123456789/14541/NASKAH\%20PUBLIK ASI_Penelitian.pdf?sequence $=1 \&$ isAllowe $\mathrm{d}=\mathrm{y}$. Diakses 21 Oktober 2017.

12. Purbadewi. 2013. Hubungan Tingkat Pengetahuan Tentang Anemia Pada Ibu hamil dengan Kepatuhan dalam mengkonsumsi Tablet Besi (Fe) di Puskesmas Keling II Kabupaten Jepara. Diakses dari http://repository.uinjkt.ac.id/dspace/bitstrea $\mathrm{m} / 123456789 / 26380 / 1 /$ Maulida\%20Nur\%2 0Soraya-fkik.pdf. Diakses 16 Oktober 2017

13. Budiarni, W, dkk. 2012. Hubungan Pengetahuan, Sikap, dan Motivasi dengan Kepatuhan Konsumsi Tablet Besi Folat pada Ibu Hamil. Journal of Nutrition Collage, Volume 1, Nomer 1tahun 2012.

14. Dahlan, Sopiyudin. 2011. Statistik Untuk Kedokteran dan Kesehatan. Jakarta: Salemba Medika.

15. Hani, Ummi, dkk. 2010. Asuhan Kebidanan Pada Kehamilan Fisiologis. Jakarta: Salemba Medika.

16. Niven, N. 2002. Psikologi Kesehatan: Pengantar untuk Perawat dan Profesional Kesehatan Lain. Penerjemah Agung Waluyo. Jakarta: EGC.

17. Fitrianingsih. 2010. Farmakologi: ObatObat Dalam Praktek Kebidanan. Yogyakarta: Nuha Medika.

18. Kadir,A. 2014. Faktor-Faktor Yang Berhubungan Dengan Kepatuhan Ibu Hamil Minum Tablet Fe di Wilayah Kerja Puskesmas Tamalanrea Kota Makassar Tahun 2013. Journal from e-library STIKES Nani Hasanuddin.08-05-2014.

19. Saifuddin. 2010. Buku Acuan Nasional Pelayanan Kesehatan Maternal dan Neonatal. Jakarta : YBP-SP

20. Almatsier, S. 2010. Prinsip Dasar Ilmu Gizi. Jakarta: PT. Gramedia Pustaka Utama.

21. Waryono. 2010. Gizi Reproduksi. Yogyakarta: Pustaka Rihama. 